\title{
PRODUK JASA LEMBAGA DAARUL QURAN TRAVEL HAJI DAN UMRAH PERSPEKTIF PEMASARAN JASA
}

\author{
Santika Pertiwi \\ STID Al-Hadid, Surabaya \\ santikapertiwi69864@gmail.com
}

\begin{abstract}
Abstrak: Tulisan ini dilatarbelakangi oleh adanya realita sebuah lembaga travel haji dan umrah yang menarik untuk dikaji, yaitu mampu memadukan antara tujuan profit dan dakwah berkelanjutan pada produk jasa yang dipasarkannya. la adalah Daarul Qur'an (Daqu) travel yang tiap tahunnya memberangkatkan 2000 jemaah. Tujuan studi untuk memaparkan produk jasa Daqu Travel dengan perspektif teori pemasaran jasa oleh Christopher Lovelock. Teori tersebut dipandang dapat mengulas produk jasa Daqu yang memiliki produk inti sekaligus beragam layanan tambahan. Tulisan ini menggunakan metode kualitatif deskriptif, dengan dokumentasi sebagai pengumpulan data. Hasil studi menunjukkan bahwa Daqu Travel memiliki produk inti yang menonjol pada pelaksanaan haji dan umrah yang khatam Quran; tersedianya pembimbing/asatidz ahli Al-Qur'an, serta Quran Call yang dapat dipakai seumur hidup. Produk inti tersebut dikelilingi oleh layanan tambahan antara lain layanan informasi melalui telepon, website, dan media sosial; layanan penerimaan pesanan yang cepat lewat aplikasi, layanan penagihan yang akurat dan terintegrasi; layanan pembayaran yang bernilai pahala sedekah; layanan konsultasi sebelum hingga selesai ibadah; layanan keramahan pada pegawai, pemberian wireless headset di tanah suci, dan tausiah selama waktu luang ibadah; layanan keamanan dan layanan pengecualian yang sesuai permintaan jemaah; hingga layanan pasca ibadah berupa kajian keagamaan, dan silaturahmi alumni yang berkelanjutan.
\end{abstract}

Kata Kunci: Produk Jasa, Pemasaran Jasa, Produk Inti, The Flower of Service, Daqu Travel Haji dan Umrah

\begin{abstract}
This discourse is grounded in a phenomenon about a hajj and umrah traveling institution interesting to study. It combines its profit-oriented purpose and sustainable dawah on its marketed service products. Daarul Quran (Daqu) is an institution that sends 2000 pilgrims every year. This study aims to describe Daqu's service products with Christopher Lovelock's services marketing theory's perspective. This theory considerably can analyze Daqu's service products including core products and various supplementary services. It uses descriptive qualitative research, with document review as a data collection method. It shows that Daqu has prominent core products, namely a hajj and umrah plus Khatam Quran package, the availability of counselor/asatidz, and Qur'an call which can be used in a lifetime. These core products are surrounded with supplementary services such as information in the call center, website, and social media; fast order-taking service through application, accurate and integrated billing service; payment service worth the merit of sadaqah; consultation service before and after rituals, hospitality service from the employees, facilitating wireless headset in the holy city, and sermon during free time; safekeeping service and exceptions service as requested by the pilgrim; and postpurchase services such as religious lectures and regular alumnus gathering

Keywords: Service product, Core Product, Supplementary service, Daqu Travel Haji dan Umrah, the flower of service
\end{abstract}




\section{Pendahuluan}

Definisi Jasa menurut Lovelock adalah suatu aktivitas ekonomi yang ditawarkan oleh satu pihak kepada pihak lain yang dilakukan dalam jangka waktu tertentu dan dalam bentuk suatu kegiatan yang akan membawa hasil yang diinginkan. Jasa memiliki empat karakteristik yang dapat memengaruhi dalam membuat desain program, yaitu tak berwujud, tak terpisahkan, bervariasi, dan tidak tahan lama. ${ }^{1}$ Oleh karenanya, jasa berbeda dengan manufaktur, yang berwujud dan bisa dimiliki. Lovelock menyatakan, ketika mengembangkan strategi untuk barang manufaktur, pemasar mengacu pada 4 elemen dasar strategi, yaitu produk, harga, lokasi, dan promosi (4P). Sedangkan pemasaran jasa mengacu pada 7P (Produk, Place, Promotion, Price, People, Process, dan Physical Evidence) atau dikenal dengan bauran pemasaran jasa, karena sifat-sifat jasa memiliki tantangan pemasaran yang berbeda yang memerlukan adaptasi dan perluasan dan digunakan untuk menciptakan strategi yang layak dalam memenuhi kebutuhan konsumen sekaligus menghasilkan laba dalam pasar yang kompetitif. ${ }^{2}$

Pada pemasaran jasa, yang menjadi inti strategi adalah produk. Jika produk didesain dengan buruk, tidak akan memberikan nilai yang penting bagi pelanggan. Produk jasa adalah seluruh elemen pemberian layanan, baik yang berwujud maupun nirwujud yang sesuai kebutuhan dan keinginan pelanggan sehingga mampu menciptakan nilai bagi pelanggan. ${ }^{3}$ Produk jasa terdiri dari produk

1 Christopher Lovelock, Jochen Wirtz, dan Jacky Mussry, Pemasaran Jasa: Manusia, Teknologi, Strategi perspektif Indonesia jilid 1 (Jakarta: Erlangga, 2010), 39

2 lbid.

${ }^{3}$ lbid., 98. inti dan layanan tambahan, merupakan satu kesatuan yang saling mendukung dan menguatkan. Seperti bisnis manufaktur, perusahaan jasa yang baik menggunakan pemasaran untuk memosisikan diri mereka sendiri secara kuat dalam pasar sasaran terpilih. ${ }^{4}$ Dengan demikian, menerapkan pemasaran jasa sangat penting bagi perusahaan maupun lembaga jasa, khususnya membuat rumusan produk jasa yang baik.

Entitas jasa dapat ditemukan di manamana. Dalam sektor swasta nirlaba, bisa dijumpai pada yayasan sosial, museum, sekolah, LBH, LSM, lembaga keagamaan, dan selainnya. Di sektor bisnis, bisnis jasa mencakup beragam usaha seperti bank, hotel, agen properti, dan biro perjalanan atau travel. ${ }^{5}$ Lembaga travel haji dan umrah adalah salah satu perusahaan yang bergerak pada bidang jasa pelaksanaan ibadah keagamaan, karena menawarkan pelayanan pelaksanaan ibadah mulai dari persiapan, pemberangkatan, pelaksanaan di tanah suci, hingga kembali ke negara asalnya. Untuk itu, aktivitas pemasaran jasa sangat dibutuhkan dalam memasarkan produk travel haji dan umrah, utamanya pada perumusan produk jasa yang tepat. Travel haji dan umrah tidak bisa hanya mengutamakan meraih profit semata, namun juga harus mampu merumuskan produk jasanya berdasarkan nilai-nilai agama. Hal itu disebabkan oleh kebutuhan jemaah yang memakai jasa travel umrah untuk melaksanakan ibadah, mendapatkan pengalaman spiritual, mendekatkan diri

\footnotetext{
${ }^{4}$ Philip Kotler dan Gary Armstrong, Prinsip-prinsip Pemasaran Edisi 12 (Jakarta: Penerbit Erlangga, 2008), 293.

5 Fandy Tjiptono, Strategi Pemasaran, Edisi 4 (Yogyakarta: Penerbit ANDI, 2015), 265.
} 
kepada Allah, dan menjalankan kewajiban rukun Islam kelima sehingga menyempurnakan keimanannya. Ibadah haji dan umrah juga termasuk ibadah yang paling mahal dari aspek pembiayaannya, sehingga pelanggan akan sangat berhatihati untuk memilih penyedia travel yang tepat di antara banyaknya lembaga biro perjalanan haji dan umrah. Dengan adanya preferensi pasar tersebut, menjadi penting bagi lembaga travel umrah untuk memiliki produk jasa yang kompetitif dan memberikan layanan yang bernilai lebih dari selainnya hingga jemaah merasakan kepuasan dalam beribadah secara kaffah.

Saat ini di Indonesia telah bermunculan beragam jasa travel haji dan umrah. Namun tidak semua memiliki layanan tambahan khusus yang menjadi pembeda dengan selainnya. Padahal menurut studi, makin tinggi pelayanan khusus yang diberikan sebuah biro perjalanan umrah dan haji khusus, maka tingkat persepsi kenyamanan yang diperoleh konsumen dalam menjalankan ibadah umrah dan haji khusus makin meningkat. ${ }^{6}$ Oleh karenanya, Daqu Travel merupakan salah satu yang menarik di antara travel sejenisnya. Selain memberikan layanan pelaksanaan haji dan umrah di tanah suci. Mereka menyisipkan berbagai produk layanan tambahan dan nilai-nilai dakwah untuk lebih memahami ajaran Islam dalam berbagai produk yang ditawarkan. Mereka juga termasuk travel

\footnotetext{
6 Mohammad Savier Azmy dan Asnan Furinto, “analisis Faktor-faktor yang Mempengaruhi Persepsi Konsumen Dalam Pemilihan Biro Perjalanan Umrah dan Haji Khusus," Journal of Business Strategy and Execution vol. 1, no.1 (November 2008): 188.

7 Qommaria Rostanti, "Daqu Travel Ajak Jamaah Umrah Khataman Alquran," Republika.co.id, diakses 23 Juli 2019, https://www.republika.co.id/berita/jurnal-
}

yang sukses dibuktikan dengan Daqu Travel mengalami pertumbuhan jemaah hingga 300\% dari tahun 2016 hingga tahun 2019, yang setiap tahunnya mampu memberangkatkan hingga 2000 jemaah. $^{7}$

Daqu Travel memberikan bimbingan belajar Al-Qur'an gratis meski jemaah sudah melaksanakan ibadah. Selain itu, adanya prinsip Haji dan Umrah "Berkah" mengajak masyarakat untuk ikut bersedekah jika ibadah bersama Daqu Travel, yaitu jemaah yang membayar umrah maupun haji sekaligus bersedekah untuk pengembangan Pesantren Tahfiz Daarul Quran serta Program Pembibitan Penghafal Al-Qur'an. ${ }^{8}$ Sehingga jemaah yang melaksanakan ibadah umrah dan haji bersama Daqu Travel mendapatkan nilai spiritual yang tidak hanya sekadar menjalankan ibadah haji dan umrah saja, tapi sekaligus bersedekah, mendapatkan ilmu pengetahuan agama, dan bimbingan belajar Al-Qur'an gratis. Menurut Ustaz Yusuf Mansur, Daqu Travel terus memberikan bantuan dan bimbingan kepada seluruh jemaahnya, semuanya disiapkan agar jemaah yang pergi umrah maupun haji bukan hanya untuk selfie atau asal tahu, melainkan agar jemaah setelah kembali dari tanah suci bisa maqbul dan mabrur. ${ }^{9}$ Bahkan hasil keuntungan Daqu Travel juga digunakan untuk program tersebut. Hal tersebut dapat menunjukkan dukungan Daqu Travel terhadap pengembangan dakwah. ${ }^{10}$

\footnotetext{
haji/berita-jurnal-haji/17/04/05/onxmbi313-daqutravel-ajak-jamaah-umrah-khataman-alquran.

${ }_{8}$ Daqutravel.com/home

9 "Hasil Investigasi Travel Umroh Haji" Video YouTube, 4:11, dikirim oleh "Daqu Travel Banten", Maret 27, 2019. https://youtu.be/rNVLWBsvkzQ 10 "Umroh Amanah, Aman - Nyaman - Berkah", Daqu Travel Banten, diakses 25 Juni 2020, https://www.daqutravelbanten.com/umrohamanah/
} 
Dari keunikan itulah dapat membuat para jemaah tertarik dan berkesan dengan Daqu Travel. Sehingga menarik untuk mengkaji produk jasa Daqu Travel yang sarat layanan tambahan bermuatan dakwah. Hal itu didukung bahwa mereka memiliki produk jasa bernilai profit maupun bernilai dakwah, bukan hanya menawarkan produk umrah, haji dan wisata hikmah pada umumnya. Rumusan masalah pada studi ini yaitu Bagaimana deskripsi produk jasa Daqu Travel dari perspektif teori pemasaran jasa? Sedangkan tujuannya untuk mendeskripsikan produk jasa yang diberikan oleh Daqu Travel kepada jemaahnya berdasarkan teori pemasaran jasa oleh Christopher Lovelock. Adanya studi ini diharapkan menjadi tambahan referensi dalam mengembangkan produk jasa pada bidang pelaksanaan ibadah keagamaan maupun bidang dakwah yaitu dengan mengembangkan produk yang mampu memadukan antara tujuan dakwah pada aspek religius maupun memberikan keuntungan bagi pengembangan lembaga dakwah. Sedangkan bagi dai, dapat menjadi referensi untuk memberikan nilai-nilai dakwah pada lembaga wisata religi melalui produk jasa.

Kajian terdahulu yang mengkaji tema sejenis antara lain Produk Dakwah Masjid Jogokaryan Periode Tahun 2000-2018. ${ }^{11}$ Kajian tersebut berfokus mengkaji bagian produk yang diberikan oleh Masjid menggunakan teori Pemasaran Jasa Christopher Lovelock, jenis penelitian deskriptif kualitatif dan metode pustaka.

11 Siti Hartinah, "Deskripsi Produk Dakwah Masjid Jogokariyan Yogyakarta Periode tahun 2000-2018" (Skripsi, STID Al Hadid, Surabaya), 116.

${ }^{12}$ Ajeng Tania, "Analisis Program Pelayanan Jama'ah Haji dan Umroh PT. Arminareka Perdana," (Skripsi, UIN Syarif Hidayatullah Jakarta, 2014).
Hasil dari studi tersebut yaitu menjelaskan bagaimana produk dakwah yang diberikan oleh Masjid Jogokaryan selama tahun 20002018 kepada jemaahnya baik di bidang manajemen, pemasaran, ibadah, ekonomi, pendidikan, kesehatan, seni dan budaya, serta bidang sosial. Kedua, tentang Analisis Program Pelayanan Jama'ah Haji dan Umroh PT. Arminareka Perdana. ${ }^{12}$ Kajian tersebut berfokus meneliti program pelayanan yang diberikan kepada jemaahnya, menggunakan motode penelitian deskriptif. Hasil penelitiannya yaitu berupa layanan administrasi, transportasi, akomodasi, konsumsi, kesehatan, serta faktor pendukung dan penghambat dalam memberikan pelayanan kepada jemaah. Selanjutnya tentang Upaya Peningkatan Pelayanan dan Loyalitas Customer Daqu Travel. ${ }^{13}$ Tujuannya membahas upaya yang dilakukan oleh Daqu Travel untuk meningkatkan loyalitas dan pelayanan terhadap customer, jenis penelitian deskriptif kualitatif menggunakan metode observasi langsung, wawancara, analisis dokumen serta studi kepustakaan. Hasil kajian yaitu pembuatan rancangan aplikasi Customer Relationship Manajemen untuk meningkatkan loyalitas dan pelayanan kepada konsumen.

Dari pemaparan studi terdahulu, penelitian mengenai layanan Daqu Travel masih belum ada yang spesifik membahas mengenai pemaparan produk jasa mulai dari produk inti maupun produk tambahannya menggunakan teori pemasaran jasa Christopher Lovelock. Sedangkan, pada

\footnotetext{
13 Ridwan Nur Padillah dan Hestya Patrie, "Upaya Peningkatan Pelayanan dan Loyalitas Customer di PT. Al Amin Mulia Lestari," Jurnal Idealis vol. 1, no 5 (2018): 231.
} 
studi ini akan menguraikan layanan apa saja yang diberikan oleh Daqu Travel kepada jemaahnya dalam perspektif teori Pemasaran Jasa Christopher Lovelock. Studi ini akan membedah layanan inti maupun tambahan yang dapat memperkuat maupun mempermudah, yang unik, dan unggul dari Daqu Travel, serta dapat memadukan nilai profit dan nilai dakwah. Maka dari itu, berdasarkan kajian terdahulu menunjukkan bahwa studi ini baru dan berbeda dari studi sebelumnya.

Metodologi studi ini berupa kualitatif deskriptif, teknik pengumpulan data menggunakan metode dokumentasi karena banyak mengkaji data-data dari laman perusahaan mulai dari gambar, video, dan tulisan. Menurut Sugiyono, metode dokumentasi merupakan teknik pengumpulan data yang berasal dari catatan peristiwa yang sudah berlalu, bisa berbentuk tulisan, gambar, atau karyakarya monumental dari seseorang. ${ }^{14}$ Sumber data primer yang digunakan adalah web resmi Daqu Travel, Instagram, Facebook dan YouTube Daqu Travel. Data juga dilengkapi dengan referensi dari liputan berita terkait Daqu Travel, serta jurnal maupun skripsi yang membahas tentang Daqu Travel dengan sumber yang kredibel. Informasi yang akan diteliti yaitu mulai dari tahun 2016-2019. Teknik analisis data kualitatif yang digunakan sesuai dengan konsep Miles, Huberman Spradley yaitu berupa reduksi data, penyajian data, dan penarikan kesimpulan. ${ }^{15}$ Studi ini menggunakan teori Pemasaran Jasa

14 Sugiyono, Memahami Penelitian Kualitatif, (Bandung: CV. Alfabeta, 2014), 82.

${ }^{15}$ Matthew B. Miles and A. Michel Huberman. Analisis Data Kualitatif. Translated by Tjetjep Rohendi Rohidi (Jakarta: UI Press, 1992), 15.

${ }^{16}$ Lovelock, Pemasaran Jasa, xiii.
Christopher Lovelock karena sebagai salah satu teori produk jasa yang telah menjadi acuan di dunia baik akademisi maupun praktisi. ${ }^{16}$ Teori tersebut dapat digunakan untuk mengulas produk secara komprehensif, yaitu mengulas produk inti dan membedah ragam layanan tambahan yang ada pada produk jasa, sebagaimana yang dimiliki oleh Daqu Travel.

\section{Produk Jasa dalam Perspektif Pemasaran Jasa}

Konseptualisasi pemasaran jasa berawal dari konsep pemasaran. Menurut Kotler, pemasaran merupakan proses sosial dan manajerial di mana pribadi atau organisasi memeroleh apa yang mereka butuhkan dan inginkan melalui penciptaan dan pertukaran nilai dengan yang lain. Karenanya, dapat dimaknai pemasaran sebagai proses di mana organisasi menciptakan nilai bagi pelanggan dan membangun hubungan yang kuat dengan pelanggan untuk menangkap nilai dari pelanggan sebagai imbalannya. ${ }^{17}$ Sedangkan jasa adalah kegiatan yang ditawarkan kepada pasar dalam jangka waktu tertentu yang dapat memberikan manfaat dan nilai positif untuk pasar, namun pasar biasanya tidak memiliki hak milik dari fasilitas fisik atas pelayanan jasa yang diberikan. ${ }^{18} \mathrm{Hal}$ senada juga disampaikan Kotler, yaitu jasa adalah tindakan atau kinerja yang ditawarkan kepada pasar yang tidak berwujud dan tidak menghasilkan kepemilikan apapun. ${ }^{19}$ Jasa memiliki empat karakteristik yang dapat memengaruhi dalam membuat desain

\footnotetext{
${ }^{17}$ Kotler dan Armstrong, Prinsip-prinsip Pemasaran, 6.

18 Lovelock, Pemasaran Jasa, 16.

19 Philip Kotler dan Kevin Lane Keller, Manajemen Pemasaran, Edisi 13 Jilid 2 (Jakarta: Erlangga, 2009), 36.
} 
program, yaitu tak berwujud, tak terpisahkan, bervariasi, dan tidak tahan lama. ${ }^{20}$ Dengan demikian, pemasaran jasa adalah adalah suatu proses sosial dan manajerial dalam menawarkan jasa oleh penyedia jasa kepada pihak lain sehingga memberikan nilai yang saling menguntungkan.

Salah satu bagian penting dalam bauran pemasaran adalah produk. Menurut Kotler \& Keller, produk adalah segala sesuatu yang bisa ditawarkan kepada pasar untuk memenuhi kebutuhan dan keinginannya. ${ }^{21}$ Produk memiliki lima tingkatan produk yang membentuk hirarki nilai pelanggan, yaitu a) core benefit, berupa manfaat inti yang dibeli pasar; b) basic product, yaitu mengubah manfaat ini menjadi produk dasar; c) expected product, menyiapkan produk yang diharapkan; d) augmented product, produk tambahan yang melebihi harapan pasar, dan produk potensial yang mencakup semua kemungkinan tambahan dan transformasi yang akan dialami produk di masa depan. ${ }^{22}$ Dari penjelasan di atas dapat disimpulkan bahwa produk jasa adalah manfaat yang diberikan kepada pasar berupa layanan tidak berwujud sesuai kebutuhan dan keinginan pasar yang memiliki jangka waktu tertentu untuk mendapatkan sumber daya pasar.

Pada konsep pemasaran jasa oleh Lovelock, produk jasa terdiri dari produk inti yang menjawab kebutuhan utama pasar dan produk tambahan berupa pelengkap

\footnotetext{
20 Ibid, 39.

${ }^{21}$ Philip Kotler dan Kevin Lane Keller, Manajemen Pemasaran, Edisi 12 (Jakarta: PT Indeks, 2007), 4.

22 Muhammad Sutio, "Pengaruh Tingkatan Produk Terhadap Loyalitas Pelanggan (The Effect of Product Level On Customer Lotalty)," Jurnal Digest Marketing vol. 3, no. 1 (2018): 54.
}

produk inti, berguna untuk mempermudah dan memperkuat nilai tambah produk yang membantu pasar menggunakan produk inti secara lebih efektif, serta dapat menjadikan diferensiasi produk dengan produk pesaing. ${ }^{23}$

Dalam sebuah produk terdapat unsur atau nilai utama yang ditawarkan kepada pasar yang dapat memberikan manfaat berupa solusi yang dicari pasar. ${ }^{24}$ Maka dari itu, produk inti adalah sebuah nyawa dari produk jasa, karena produk inti membahas mengenai masalah utama dari pasar, dan pemasar memberikan sebuah pemecahan pada masalah utama yang dirasakan langsung oleh pasar. Kualitas produk terdiri dari fasilitas fisik, keandalan berupa pelayanan yang cepat dan tepat, ketanggapan, jaminan dan kepastian, serta empati. ${ }^{25}$ Sedangkan manfaat produk dapat berupa fasilitas fisik, keamanan, kemudahan, pengalaman spiritual, kenyamanan, dan sebagainya sesuai kebutuhan pasar.

Produk inti dikelilingi oleh layanan-layanan tambahan lainnya untuk menguatkan adanya produk inti sehingga dapat memenuhi kepuasan pelanggan secara utuh. Layanan-layanan tambahan dapat diklasifikasikan menjadi delapan kelompok atau disebut The Flower of Service, karena delapan layanan tersebut bisa dianalogikan dengan sebuah kelopak bunga yang mengelilingi produk atau layanan inti. Pada masing-masing kelopaknya memiliki peran

\footnotetext{
${ }^{23}$ Lovelock, Pemasaran Jasa, 25.

24 Ibid, 98.

25 Siti Fatona, "Kualitas Jasa yang Memengaruhi Loyalitas dan Relevansinya Terhadap Kepuasan," Jurnal Dinamika Manajemen vol. 1, no. 1 (2010): 43.
} 
masing-masing untuk mendukung satu sama lain, sehingga ketika salah satu elemen pada kelopak tidak bekerja dengan baik, masih ada kelopak lain yang dapat membantu, sehingga tidak akan membuat keseluruhan elemen dari produk menjadi gagal. ${ }^{26}$

Layanan tambahan yang pertama adalah layanan informasi yang diberikan kepada pasar dengan tepat sesuai kebutuhannya yang berhubungan dengan produk, sehingga akan makin jelas terkait produk yang diberikan kepada pasar untuk mendapatkan nilai penuh dari produk tersebut. Informasi yang diberikan harus relevan dengan produk, dalam waktu yang tepat, dan isinya akurat. Jika telat dan salah dalam memberikan informasi akan membuat pasar merasa terganggu dan tidak nyaman sehingga tercipta ketidakpuasan terhadap layanan yang diberikan. ${ }^{27}$

Kedua layanan penerimaan pesanan yang dilakukan ketika calon pelanggan sudah memutuskan untuk melakukan pemesanan. Penerimaan pesanan yang baik yaitu dilaksanakan dengan sopan, cepat, akurat, serta lebih efisien secara waktu, tenaga bahkan biaya agar sumber daya yang dikeluarkan pasar tidak besar saat melakukan pemesanan. Penerimaan pesanan dapat berupa pencarian data oleh penyedia layanan jasa kepada calon pasar untuk mendapatkan data-data yang dibutuhkan sehingga dapat memudahkan saat memberikan layanan. ${ }^{28}$

Layanan tambahan selanjutnya adalah melakukan layanan penagihan yang

26 Lovelock, Pemasaran Jasa, 101.

27 lbid, 101-102.

$28 \mathrm{lbid}, 102$. bertujuan untuk mendorong pembayaran layanan. Penagihan harus tepat waktu karena dapat menstimulus pembayaran yang lebih cepat dan pasar tidak menunggu lama, bahkan dengan teknologi yang canggih, penagihan dan pembayaran tergabung dalam satu tindakan sehingga dapat menghemat waktu bahkan lebih akurat, dan terbaca dengan jelas. Pasar biasanya mengharapkan tagihan yang jelas dan informatif, dan dirinci sehingga jelas perhitungan jumlahnya agar dapat memberikan kesan menarik. ${ }^{29}$

Berikutnya, layanan pembayaran yang diberikan kepada pasar yang hendak melakukan transaksi pembelian. Pembayaran dapat dilakukan dengan cara transfer mesin, memberikan uang tunai kepada pegawai, serta dapat juga dilakukan secara online agar lebih mudah, aman dan nyaman saat proses pembayarannya sesuai yang diharapkan oleh pasar. ${ }^{30}$

Selain itu, sebuah perusahaan dapat menyediakan layanan konsultasi berupa respon sederhana hingga memberikan solusi untuk menjawab masalah pada pasar yang dilakukan dengan cara melakukan dialog untuk mengetahui kebutuhan atau masalah pasar. Inti dari layanan konsultasi menurut Lovelock berupa "solution selling" yang ditawarkan kepada pasar agar nilai manfaat yang dirasakan oleh pasar menjadi lebih berharga dari nilai layanan yang telah diterima sebelumnya sehingga muncul kepuasan saat mengonsumsi jasa atau layanan inti yang diberikan kepada pasar. ${ }^{31}$ Selanjutnya, berupa layanan keramahan yang dilakukan saat pasar menunggu

\footnotetext{
29 Ibid, 103-104.

30 Ibid, 104-105.

31 Ibid, 105-106.
} 
pemberian produk inti. Layanan keramahan ini dapat menjadi diferensiasi produk sehingga merupakan keunggulan dari suatu lembaga karena tidak diberikan oleh lembaga pesaing. Dalam layanan keramahan, pegawai harus menciptakan atmosfir yang ramah dan pengalaman yang berkesan, sehingga perlu memiliki pegawai yang ramah secara sikap, penampilan, dan perilaku. Keramahan yang diberikan kepada pasar dapat berupa salam, menyediakan makanan dan minuman, toilet dan kamar mandi, serta fasilitas lainnya. ${ }^{32}$

Layanan tambahan lainnya adalah layanan penyimpanan yaitu bantuan yang diberikan kepada pasar untuk barang bawaan mereka ketika pasar mengunjungi tempat layanan, yaitu layanan yang disediakan untuk menyimpan dan menjaga barang-barang milik pasar dengan baik. Serta layanan berbentuk fisik yang diberikan kepada pasar untuk menyimpan barang-barang milik pasar, misalnya berupa tas pelindung, transportasi pengantaran barang, dan sebagainya. ${ }^{33}$ Layanan penyimpanan juga dapat diwujudkan dengan memberikan perhatian yang tinggi pada masalah keselamatan dan keamanan pasarnya yang mengunjungi fasilitas jasa mereka. ${ }^{34}$

Terakhir, berupa Layanan Pengecualian merupakan layanan tambahan yang berada di luar kebiasaan selama pemberian layanan. Yaitu layanan yang tidak terdapat di dalam penawaran layanan normal yang biasanya ditawarkan kepada pasar. Layanan ini diberikan ketika terdapat masalah pasar

\footnotetext{
$32 \mathrm{Ibid}$.

${ }^{33}$ Ibid, 107-108.

${ }^{34}$ Christopher H. Lovelock and Lauren K. Wright, Manajemen Pemasaran Jasa (Jakarta: Indeks, 2005), 202.

35 Ibid.
}

yang tak terduga. Layanan pengecualian dapat berupa permintaan khusus, pemecahan masalah, penanganan keluhan, dan restitusi. ${ }^{35}$

\section{Profil Daqu Travel}

Daqu Travel merupakan biro perjalanan yang memberikan bimbingan dengan layanan penyelenggaraan ibadah haji, umroh, dan wisata hikmah secara maksimal kepada seluruh jemaah. Daqu Travel Haji dan Umrah tersebut milik PPPA Daarul Quran yang didirikan sejak tahun 2000 oleh salah satu tokoh agama terkenal yaitu Ustaz Yusuf Mansur yang saat ini memiliki posisi sebagai pembina. ${ }^{36}$ Daqu Travel memiliki izin resmi yang sudah dikeluarkan oleh Kementerian Agama R.I. dan merupakan salah satu anggota dari Himpunan Penyelenggara Umrah dan Haji Khusus (HIMPUH), yang merupakan salah satu organisasi resmi di bawah naungan Kementerian Agama Republik Indonesia selain Asosiasi Muslim Penyelenggara Haji dan Umrah Republik Indonesia (AMPHURI), Kesatuan Tour Travel Haji dan Umrah Republik Indonesia (KESTHURI), dan Asosiasi Penyelenggara Haji Umrah dan InBound Indonesia (ASPHURINDO). Travel yang telah memiliki lima perwakilan di berbagai kota di seluruh Indonesia ini yang disebut dengan Sahabat Daqu Nusantara menyediakan berbagai program perjalanan ibadah haji khusus dan umrah yang direncanakan menggunakan akomodasi dan transportasi yang nyaman dan aman. ${ }^{37}$

\footnotetext{
36 "Profil Perusahaan," DAQU TOUR AND TRAVEL: Umroh, Haji dan Wisata Muslim, diakses Juli 23, 2019, https://daqu-travel.com/tentang-kami.

37 Pueri Sa'ada Natasari, "Strategi dan Pelaksanaan Komunikasi Pemasaran Terpadu DAQU Travel Tahun
} 
Visi Daqu Travel yaitu menjadi biro perjalanan haji dan umroh serta wisata hikmah yang profesional dengan memberikan pelayanan terbaik serta mengutamakan kepuasan para jemaah. Dengan misi yaitu melayani jemaah dengan kualitas pelayanan terbaik, mengutamakan kepuasan jemaah dalam beribadah, dan memberikan kontribusi terhadap program pembibitan penghafal Quran. ${ }^{38}$

Daqu Travel memiliki motto AMANAH untuk menunjukkan keunggulan yang dimilikinya yaitu Aman, Nyaman, Berkah. Aman karena Daqu Travel adalah salah satu unit usaha dari Yayasan Daarul Quran yang dibina oleh K.H. Yusuf Mansur dan sudah memenuhi kriteria Lima Pasti Umrah yang ditetapkan oleh Kementerian Agama R.I., yaitu Pasti Travelnya, Pasti Jadwalnya, Pasti Terbangnya, Pasti Hotelnya, dan Pasti Visanya. Nyaman karena dibimbing oleh Asatidz 39 Daarul Quran yang telah berpengalaman dan ahli Al-Qur'an, pengadaan manasik yang dilakukan menginap di hotel sebelum keberangkatan, serta memberikan layanan terbaik lainnya. Berkah karena langsung mengikuti program sedekah untuk Program Penghafal AlQur'an dan pengembangan Yayasan Daarul Quran, sekaligus mengikuti program Quran Call untuk belajar membaca dan menghafal Al-Qur'an melalui telepon dan gratis. ${ }^{40}$

2013" Skripsi, Universitas Muhammadiyah Jakarta. 2015, 74.

$38 \mathrm{lbid}, 77-78$.

${ }^{39}$ Asatidz merupakan kata jamak dari Ustaz yang memiliki makna guru. Dengan demikian, bahwa guru atau ustaz dapat dikatakan seperti seorang pendidik, yang ikut berperan dalam usaha pembentukan sumber daya manusia yang potensial dibidang pembangunan. Maka dari itu, Asatidz harus berperan secara aktif dan menempatkan kedudukannya secara profesional sesuai dengan tuntutan masyarakat yang makin berkembang. Dalam Miftahul Ulum,

\section{Produk Inti Daqu Travel}

Pada bagian ini, akan dianalisis mengenai produk inti dari Daqu Travel. Menurut Lovelock, produk inti merupakan solusi yang ditawarkan kepada jemaah yang dapat memberikan manfaat sesuai dengan masalah atau kebutuhan utama jemaahnya. ${ }^{41}$ Sehingga produk inti Daqu adalah yang menjadikannya memiliki keunggulan dan dipandang bisa memenuhi kebutuhan jemaahnya akan ibadah haji dan umrah yang kaffah. Haji merupakan rukun Islam yang kelima, sehingga menjadi citacita bagi setiap muslim untuk bisa memenuhinya untuk menyempurnakan ibadah. Sedangkan umrah merupakan bagian dari ritual dalam haji, hingga disebut sebagai ibadah haji kecil. Meski demikian, pada sebuah studi diungkapkan umrah adalah sunnah yang juga diidam-idamkan oleh seluruh umat Islam. Tak hanya karena ingin mendapatkan kesempatan untuk memuja Allah Swt., namun juga karena umrah adalah perjalanan luar biasa. Umrah merupakan ibadah sunnah yang multidimensi, baik dari sisi ruhani dan spiritualitas seorang muslim, begitu juga dengan dimensi fisik, dan kemampuan materi. ${ }^{42}$ Oleh karenanya kebutuhan umat muslim atas keduanya sangat tinggi, pada aspek pemenuhan spiritual, fisik, dan sosial. Untuk bisa memenuhi kebutuhan ibadah

"Pembinaan Kompetensi Ustadz Madrasah Diniyah Melalui Program Tarbiyatul Mu'allimin di Madrasah Diniyah Takmiliyah Awwaliyah Ar-Rosyidiyah Mambaul Ulum Pangarengan Sampang," Modeling: Jurnal Program Studi PGMI vol. 6, no. 2 (2019): 137. 40 "Mengapa Memilih Daqu Travel?," DAQU TRAVEL, diakses Juli 23, 2019. https://daqutravel.com/home.

${ }^{41}$ Lovelock, Pemasaran Jasa, 98.

42 Subkhani Kusuma Dewi, "Trend Wisata Umrah: Antara Meneladani Sunnah dan Turisme Spiritual," Empirisma vol. 26, no. 2 (2017): 191. 
tersebut, Daqu Travel memberikan ragam produk, pertama, umrah reguler, yaitu perjalanan ibadah umrah yang dilaksanakan minimal sembilan hari perjalanan mulai dari keberangkatan hingga kembali ke tanah air. Umrah plus, yaitu paket perjalanan umrah yang dirangkai dengan tour wisata ke negara-negara lain. Kedua, umrah Ramadan, yaitu umrah yang dilaksanakan ketika bulan Ramadhan yang memiliki tiga grup keberangkatan yaitu awal Ramadan, Nuzulul Quran, dan Lailatul Qadar. Terakhir, Haji khusus adalah penyelenggaraan ibadah haji khusus yang dikelola oleh Daqu Travel yang telah memiliki izin resmi dari Kementerian Agama RI. ${ }^{43}$ Pada kesemua produk tersebut, terdapat jasa yang ditawarkan untuk memenuhi kebutuhan utama jemaahnya, yaitu mulai dari pengurusan visa, transportasi, makan tiga kali sehari, layanan menginap di hotel selama di tanah suci, transportasi bus berac, muthawif pendamping merupakan asatidz Pesantren Daarul Quran yang telah berpengalaman, perlengkapan umrah/haji, air zam-zam, dan asuransi perjalanan. ${ }^{44}$

Pembimbing jemaah Daqu Travel yang berasal dari Asatidz Daarul Quran merupakan ulama dan councelor agama, menguasai Al-Qur'an dan hadis sebagai hukum ibadah dan lulusan Kairo. Biasanya travel haji dan umrah lainnya hanya menggunakan muthawif atau pembimbing biasa atau seperti tour leader saja. Namun Daqu Travel memiliki Asatidz sebagai pembimbing ibadah dan muthawif sebagai pemandu wisata. ${ }^{45}$ Dari adanya bimbingan

\footnotetext{
${ }^{43}$ Daqutravel.com/home

${ }^{44}$ Daqutravel.com/umrah; daqutravel.com/haji

${ }^{45}$ Natasari, "Strategi dan Pelaksanaan Komunikasi Pemasaran Terpadu DAQU Travel Tahun 2013," 83.

46 Qommaria Rostanti, "Daqu Travel Ajak Jamaah Umrah Khataman Alquran."
}

manasik haji, bimbingan ibadah baik wajib maupun sunnah oleh pembimbing profesional, menunjukkan bahwa Daqu Travel membantu jemaah agar maksimal beribadah dan bermunajat kepada Allah sesuai tuntutan Islam. Hal tersebut sesuai dengan prinsip Daqu Travel yang ingin memberikan kenyamanan, keamanan, serta kemudahan dalam beribadah, sehingga kebutuhan jemaah untuk menjalankan ibadah dengan aman dan nyaman dapat terlaksana dengan baik. Pembimbing termasuk dalam produk inti pada travel haji dan umrah, sebab keberadaannya mutlak ada, dan Daqu mampu menyediakannya dengan kualifikasi yang baik.

Kegiatan ibadah haji dan umrah bersama Daqu Travel juga sekaligus mengadakan khataman Al-Qur'an. Jasa ini merupakan produk inti karena merupakan hal yang ditonjolkan oleh Daqu Travel dan mampu menarik minat jemaah yang memiliki keinginan untuk melengkapi ibadah haji dan umrah dengan mengkhatamkan Al-Qur'an selama di tanah suci bahkan menjadi program wajib dilakukan oleh jemaah Daqu Travel. Selama perjalanan umrah, biasanya jemaah hingga dua kali mengkhatamkan AlQur'an selama di Mekkah dan Madinah. ${ }^{46}$ Pelaksanaan program tersebut dilakukan dengan dibuatnya grup WhatsApp untuk membimbing dan memantau jemaah. Menurut Daqu Travel selama program tersebut, semua jemaah senantiasa menyetor bacaan Al-Qur'an yang sudah dibaca dan dihafal melalui grup tersebut. ${ }^{47}$ Hal itu menunjukkan bahwa animo jemaah

https://www.republika.co.id/berita/jurnalhaji/berita-jurnal-haji/17/04/05/onxmbi313-daqutravel-ajak-jamaah-umrah-khataman-alquran. 47 "Launching Program Umroh $1441 \mathrm{H}$," video Youtube, 1:14:55, dikirim oleh "Daqu Channel," Mei 3, 2019. https://youtu.be/vzZHBTK3xZk. 
untuk mengikuti khataman Quran tinggi, dan nyatanya menjadi salah satu daya tarik produk Daqu travel dibanding biro perjalanan lainnya. Ini didukung salah satunya melalui liputan bahwa jemaah daerah Sukabumi tertarik memilih Daqu Travel dikarenakan ingin mengikuti program Khataman Quran selama di tanah suci walaupun harganya bukan di bawah standar. Ustaz Yusuf Mansur menyatakan bahwa adanya program tersebut diadakan agar jemaah yang berangkat ke tanah suci mampu menjalankan ibadah dengan maqbul dan mabrur. ${ }^{48}$

Layanan tersebut merupakan solusi yang ditawarkan kepada jemaahnya untuk makin meningkatkan rasa spiritual selama di tanah suci, sesuai yang dijelaskan oleh Lovelock bahwa produk inti dapat memberikan pemecahan masalah utama yang dirasakan oleh pasar, ${ }^{49}$ salah satunya memberikan manfaat pengalaman spiritual. Pada studi lain juga menjelaskan bahwa program khataman quran merupakan produk diferensiasi Daqu Travel yang membedakan dengan travel lainnya, yang menjadi alasan jemaah memilih Daqu Travel sebagai penyelenggara ibadah haji dan umrah. ${ }^{50}$

Daqu Travel memiliki prinsip Berkah, yaitu jemaah yang menyelenggarakan ibadah haji dan umrah melalui Daqu Travel, akan diberikan layanan Quran Call seumur hidup, belajar membaca dan menghafal Al-Qur'an yang dilakukan melalui telepon dan gratis. ${ }^{51}$ Program Quran Call adalah program

48 Qommaria Rostanti, "Daqu Travel Ajak Jamaah Umrah Khataman Alquran." https://www.republika.co.id/berita/jurnalhaji/berita-jurnal-haji/17/04/05/onxmbi313-daqutravel-ajak-jamaah-umrah-khataman-alquran.

49 Siti Fatona, "Kualitas Jasa yang memengaruhi Loyalitas dan Relevansinya Terhadap Kepuasan," 43. layanan menghafal Al-Qur'an yang menggunakan fasilitas telepon selama 24 jam. Quran Call ini beraktivitas sebagai program layanan kepada masyarakat via telepon dengan pembimbing yang menguasai metode tahfidz (sima'i) dan memahami tahsin Al-Qur'an. Tujuannya untuk memberikan kemudahan kepada masyarakat yang sibuk tetapi tetap bisa belajar dan menghafal Al-Qur'an, sehingga jemaah akan dibimbing untuk belajar AlQur'an hingga lancar. Bahkan seluruh jemaah haji maupun umrah Daqu Travel juga dapat mengikuti Majelis Tahsin dan Tahfidz yang diselenggarakan oleh Pesantren Daarul Quran setiap minggunya. ${ }^{52}$ Keistimewaan produk ini juga dapat diakses seumur hidup, mulai dari masa tunggu keberangkatan haji/umrah maupun setelah selesai pelaksanaan ibadah. Kemampuan membaca Quran dewasa ini menjadi sangat populer dan sangat diminati oleh umat muslim, karena adanya pandangan besarnya nilai pahala bagi seorang muslim yang banyak membaca Quran apalagi jika sampai bisa menghafalkannya. Sehingga adanya produk jasa tersebut akan menjadi daya tarik khusus bagi jemaah untuk memilih Daqu Travel.

Program tersebut dapat dimaknai sebagai ajakan kepada masyarakat untuk menjalankan perintah Allah Swt. untuk mempelajari Al-Qur'an, dengan bisa membaca Al-Qur'an diharapkan jemaah Daqu Travel makin dekat dengan Allah Swt.

\footnotetext{
50 Natasari, "Strategi dan Pelaksanaan Komunikasi Pemasaran Terpadu DAQU Travel Tahun 2013," 106. 51 "Profil Perusahaan," DAQU TOUR AND TRAVEL: Umroh, Haji dan Wisata Muslim, diakses 08 Oktober 2019. https://daqu-travel.com/tentang-kami.

52 "Qur'an Call," PPPA Daarul Qur'an, diakses Oktober 8, 2019. https://pppa.id/program/quran_call.
} 
dan makin memahami ajaran Islam. Dengan demikian Daqu Travel juga turut menyebarluaskan ajaran Islam melalui produk tersebut.

\section{Layanan-Layanan Tambahan Daqu Travel}

\section{1) Layanan informasi}

Layanan informasi merupakan salah satu hal yang mutlak ada pada tiap produk jasa. Menurut Lovelock, pemberian informasi yang diberikan harus jelas, detail, dan relevan, sehingga dapat memberikan gambaran terkait proses mengonsumsi layanan di perusahaan atau lembaga. ${ }^{53}$ Daqu Travel memberikan layanan informasi dalam beberapa pendekatan, yaitu secara langsung dari pegawai Daqu Travel maupun melalui telepon untuk memberikan informasi dan pelayanan customer service. Sedangkan secara tidak langsung dilakukan melalui media yang dapat diakses kapan saja, seperti website, YouTube, maupun sosial media. Sehingga, bagi konsumen yang membutuhkan informasi mengenai pelaksanaan ibadah haji dan umrah, dapat menghubungi nomor kontak, mengunjungi web, maupun media sosial. Daqu Travel juga memiliki aplikasi "Umrah Daqu Travel" sebagai layanan untuk memberikan informasi sehingga memudahkan jemaah mendapatkan informasi tentang pelaksanaan ibadah di Daqu Travel, namun aplikasi tersebut hanya memberikan informasi mengenai umrah saja. ${ }^{54}$

Dari sisi konten, informasi yang diberikan oleh Daqu Travel cukup jelas, relevan dan

\footnotetext{
53 Lovelock, Pemasaran Jasa, 100-102.

54 "Profil Perusahaan," DAQU TOUR AND TRAVEL: Umroh, Haji dan Wisata Muslim, diakses 18
}

detail seperti penjelasan ibadah haji dan umrah yang aman, nyaman, dan berkah. Dilengkapi pula dengan testimoni jemaah terkait pelayanan layanan haji dan umrah Daqu Travel, harga produk haji dan umrah, keunggulan lain yang dimiliki Daqu Travel, dokumentasi kegiatan, dan hal-hal teknis lainnya terkait pelaksanaan haji dan umrah. ${ }^{55} \mathrm{Hal}$ tersebut sesuai dengan kebutuhan jemaah terkait pencarian informasi mengenai pelaksanaan haji bersama Daqu Travel, sehingga jemaah tidak kebingungan serta dapat memudahkan untuk memberikan gambaran terkait proses pelaksanaan ibadah bersama Daqu Travel. Saat memberikan informasi dari testimoni jemaahnya juga sampai ditunjukkan nama, pekerjaan, serta foto jemaahnya untuk membuktikan bahwa informasi mengenai testimoni sesuai realitasnya. Dengan begitu jemaah puas karena kebutuhan terkait informasi Daqu Travel dapat terjawab.

\section{2) Layanan penerimaan pesanan}

Setelah pasar mengetahui informasi dan memutuskan untuk memilih Daqu Travel maka pelanggan melakukan pemesanan produk inti dengan memberikan data-data terkaitnya. Menurut Lovelock pemesanan harus dilakukan dengan sopan, cepat, akurat, serta efisien. Layanan penerimaan pesanan Daqu Travel yang dilakukan secara langsung yaitu dilakukan di kantor pusat maupun kantor perwakilan daerah yang akan dibimbing langsung oleh petugas Daqu Travel. Sedangkan secara tidak langsung dilakukan secara online melalui website, dan melalui aplikasi Umrah Daqu Travel

September 2019. https://daqu-travel.com/tentangkami.

55 “Daqu Travel," Daqu Travel, diakses 15 Juni 2020. https://daqutravel.com/home. 
yang diperuntukkan untuk program umrah saja, dengan mengikuti langkah-langkah yang ada. Setelah itu ada pemberitahuan berhasil terdaftar. ${ }^{56}$

Pemesanan secara online lebih efisien karena jemaah tidak perlu berkunjung langsung ke kantor Daqu Travel, bisa dilakukan hanya dengan mengunjungi situs web maupun menngunduh aplikasi "Umroh Daqu Travel", apalagi jika terdapat calon jemaah yang rumahnya jauh dengan letak kantor Daqu Travel. Pendaftaran melalui aplikasi dan web hanya membutuhkan waktu sebentar untuk mengisi data, tidak sampai 30 menit. Pemesanan dilakukan dengan cepat dapat juga didukung dari testimoni jemaah yang mengatakan bahwa "Daqu Travel luar biasa, sejak awal mendaftar pelayanannya ramah dan serba cepat, semuanya dilakukan dengan profesional." 57 Bahkan saat pendaftaran secara online prosesnya sudah akurat, yaitu terdapat persyaratan, data-data yang harus diisi, serta langsung terhubung dengan nomor ponsel Daqu Travel. ${ }^{58}$

\section{3) Layanan penagihan}

Layanan penagihan adalah produk tambahan yang dilakukan setelah selesai melakukan pemesanan untuk mendorong pasar agar segera melakukan pembayaran. Layanan penagihan yang dilakukan oleh Daqu Travel berupa informasi pembayaran dengan sistem penagihan yang akurat, jelas, dan informatif yaitu diberitahu secara

56 "7 Alasan Kenapa Umroh Dengan Daqu Travel?," DAQU TOUR AND TRAVEL, diakses April 01, 2020. https://daqu-travel.com/7-alasan-kenapa-umrohdengan-daqu-travel.html.

57 "Profile Daqu Travel," video Youtube, 7:57, dikirim oleh "Nano Rangga MC," diakses 02 November 2019. https://youtu.be/7Da81virNSM.

58 "Berencana Umroh Dalam Waktu Dekat?," DAQU TRAVEL, diakses September 19, 2019. online dan dikomunikasikan secara langsung oleh pegawai bagian registrasi, isinya terdapat rincian dan jumlah harga yang harus dibayar oleh calon jemaah. ${ }^{59}$ Menurut Lovelock, jika tagihan yang tidak akurat, tidak terbaca, atau tidak lengkap memiliki risiko yang dapat mengecewakan pelanggan yang mungkin, sampai titik ini telah cukup puas dengan pengalaman mereka, atau lebih buruk lagi, ketidaksempurnaan seperti itu memperburuk situasi jika pelanggan sebelumnya merasa tidak puas. ${ }^{60}$ Dengan sistem penagihan melalui online yaitu jika memesan melalui website maupun aplikasi dapat dilakukan dengan cepat setelah pelanggan melakukan pemesanan, langsung muncul layar pemberitahuan melalui sms maupun notifikasi langsung berupa gambar/foto. Sistem penagihan yang dilakukan oleh Daqu Travel terdapat penagihan awal untuk membayar booking seat sesuai jumlah harga yang ditentukan. ${ }^{61}$

\section{4) Layanan pembayaran}

Layanan tambahan berikutnya yaitu layanan pembayaran yang dilakukan setelah memesan produk inti Daqu Travel dengan menyediakan pembayaran tunai dan transfer sehingga Daqu Travel sudah menyediakan rekening agar para pelanggan bisa langsung transfer ke rekening milik Daqu Travel. Yang menarik dan unik yaitu jemaah yang mendaftar dan membayar ibadah haji dan umrah di Daqu Travel, sudah termasuk bersedekah Rp.100.000,-

https://www.daqutravelbanten.com/umroh-2019/. 59 "Profile Daqu Travel," video Youtube, 7:57, dikirim oleh "Nano Rangga MC," diakses 02 November 2019. https://youtu.be/7Da81virNSM.

${ }^{60}$ Lovelock, Pemasaran Jasa, 103.

61 "Brosur Haji Terbaru," DAQU TRAVEL, diakses September 17, 2019. https://daqutravel.com/haji. 
per jemaah. ${ }^{62}$ Sedekah tersebut sudah dilakukan secara otomatis saat calon jemaah membayar uang untuk setiap produk yang dibelinya. Hal itu karena Daqu Travel memiliki prinsip berkah, yaitu pendapatan hasil bisnis umrah akan digunakan membantu mengembangkan Program Pesantren Penghafal Quran dan Pengembangan Yayasan Daarul Quran. Salah satu testimoni dari jemaahnya mengatakan bahwa jangan meragukan lembaga Daqu Travel karena tidak hanya sekadar menjalankan ibadah saja tapi sekaligus mendapatkan pahala dari sedekah. ${ }^{63}$ Dengan adanya haji dan umrah sambil sedekah ini dapat menarik perhatian khususnya masyarakat yang memiliki kebutuhan untuk bersedekah, mereka pasti memilih sesuatu yang terdapat nilai pahala yang lebih banyak. Tentunya program sedekah otomatis ini, menjadi keunggulan bagi Daqu Travel karena belum ditemui pada lembaga travel lainnya. Adanya program sedekah tersebut merupakan ajakan kepada masyarakat untuk menjalankan perintah Allah Swt. berupa bersedekah, sehingga nilai-nilai dakwah dapat tersampaikan kepada jemaah Daqu Travel.

Selain itu, Daqu Travel juga menyediakan sistem tabungan umrah maupun haji berupa layanan simpanan umroh (Simproh) yang sudah bekerjasama dengan Kopindo Berjemaah Daarul Quran. ${ }^{64}$ Layanan ini juga terdapat pada biro perjalanan haji dan

62 "Profil Perusahaan," DAQU TOUR AND TRAVEL: Umroh, Haji dan Wisata Muslim, diakses 02 Agustus 2019. https://daqu-travel.com/tentang-kami

63 "Ibadah Dapat Sedekah Pun Dapat," Instagram, dikirim oleh "daqutravel," Maret 19, 2019. https://www.instagram.com/p/BvLMYqTAZ27/?igshi $\mathrm{d}=1 \mathrm{~s} 5 \mathrm{mtt7f413ax}$.

64 "Simpanan Umroh," Instagram, dikirim oleh "daqutravel," Desember 29, 2016. umrah umumnya. Layanan tersebut memudahkan jemaah yang ingin umrah dengan sistem menabung sesuai kapasitas dana yang dimiliki oleh calon jemaah hingga terkumpul sesuai harga produk yang ingin dibeli.

\section{5) Layanan konsultasi}

Daqu Travel menyebutkan dalam website bahwa layanan konsultasi dapat dilakukan melalui telepon yaitu telepon kantor Daqu; melalui chat pada website Daqu Travel yang terhubung langsung ke chat Whatsapp; dan berkunjung ke kantor Daqu Travel. ${ }^{65}$ Menurut Lovelock, konsultasi merupakan layanan tambahan yang membantu memberikan solusi kepada pasar saat mengalami kesulitan sebelum maupun selama mengonsumsi produk, sehingga pasar merasa diperhatikan dan puas atas manfaat yang dirasakan. ${ }^{66}$ Adanya layanan konsultasi dapat membantu memberikan solusi sesuai masalah atau kesulitan dan kebingungan jemaahnya selama pelaksanaan ibadah. ${ }^{67}$ Selama pelaksanaan ibadah, jemaah juga dapat langsung berkonsultasi jika mengalami kesulitan ibadah kepada pembimbing/muthowifnya. Layanan konsultasi ini bertujuan agar calon jemaah makin percaya untuk membeli dan mengonsumsi produk haji maupun umrah dari Daqu Travel secara utuh tanpa adanya hambatan atau kebingungan apapun sehingga muncul kepuasan dari jemaah. Hal ini didukung adanya testimoni dari jemaahnya yang bernama Rachmat Hidayat

https://www.instagram.com/p/BOmKw4Thdry/?igsh id=7un1dyhuv5758.

65 "Berencana Umroh Dalam Waktu Dekat?," DAQU TRAVEL, diakses September 19, 2019.

https://www.daqutravelbanten.com/umroh-2019/.

${ }^{66}$ Lovelock, Pemasaran Jasa, 105-106.

67 "Haji Khusus," DAQU TOUR AND TRAVEL: Umroh, Haji dan Wisata Muslim, diakses 25 Juni 2020. https://daqu-travel.com/paket-haji 
bahwa Daqu Travel telah melebihi ekspektasi beliau, salah satunya dikarenakan selalu merespon dengan cepat jika jemaahnya mengalami kesulitan selama di tanah suci. ${ }^{68}$

\section{6) Layanan keramahan}

Layanan keramahan Daqu Travel dapat ditemui pada beberapa lini jasanya. Dimulai dari menerima jemaah pada awal pendaftaran maupun saat masa memilih produk melalui pegawai Daqu Travel. Pada video yang diunggah Daqu travel, dijanjikan layanan yang ramah, hangat, sopan, dan penuh dengan senyuman, bahkan mencium tangan jika jemaahnya orang tua. Pada video, terlihat jemaahnya merasa senang ketika disambut dan dihormati oleh pegawai Daqu Travel. ${ }^{69} \mathrm{Hal}$ tersebut menunjukkan bahwa Daqu Travel berusaha melayani dengan penuh keramahan, menjunjung sopan santun kepada yang lebih tua, dan perhatian sehingga dapat memberikan kepuasan kepada para jemaahnya.

Layanan keramahan sebelum berangkat haji dan umrah juga diberikan Daqu Travel dalam bentuk penginapan di hotel pada saat manasik. Bimbingan manasik Daqu Travel dilakukan dengan menginap selama satu hari sebelum keberangkatan untuk umrah di hotel, sedangkan haji menginap tiga hari dua malam. Bimbingan manasik dengan menginap di Hotel sebelum keberangkatan merupakan keunggulan bagi

68 "Melebihi Ekspektasi," Instagram, dikirim oleh "daqutravel," Februari 20, 2019. https://www.instagram.com/p/BuGY6AHAJjz/?igshid $=4$ pohvw2nbl46.

69 "Beginilah Kami Melayani Tamu Allah - Manasik Umrah Daqu Travel," Video Youtube, 4:54, dikirim oleh "Daqu Travel banten," Maret 20, 2019. https://youtu.be/a9wPaqpC6ME.
Daqu Travel karena tidak dilakukan oleh biro travel lainnya dengan menginap sebelum keberangkatan. ${ }^{70}$

Layanan keramahan bisa berupa fasilitas yang memudahkan, salah satunya Daqu Travel memfasilitasi jemaah dengan menggunakan wireless headset. Tujuannya untuk memudahkan jemaah mendengarkan panduan doa dari pembimbing pada saat tawaf dan sai di tanah suci. Adanya fasilitas tersebut dikarenakan pihak Daqu Travel melihat ada masalah dalam yaitu keriuhan suara manusia yang membaca doa dan tasbih yang akan mengganggu pendengaran jemaahnya saat mendengarkan pembimbing. Maka dari itu, Daqu Travel memfasilitasi alat tersebut agar lebih jelas mendengarkan arahan dari pembimbing sehingga dapat melaksanakan ibadah umrah dengan nyaman dan maksimal. ${ }^{71}$ Penyediaan alat tersebut termasuk salah satu keramahan yang diberikan oleh Daqu Travel, sebagai bentuk perhatian dengan memberikan manfaat atas kebutuhan tambahan dari jemaah selama menjalankan tawaf dan sai, yaitu kebutuhan alat untuk mendengarkan panduan doa dan bimbingan, dengan menggunakan alat tersebut membuat jemaah makin optimal, nyaman, dan fokus dalam menjalankan ibadah haji maupun umrah karena dapat mengatasi adanya masalah keramaian. Layanan tersebut merupakan layanan keramahan yang memiliki nilai tambah

\footnotetext{
${ }^{70}$ Muhammad Reza, "Evaluasi Pelayanan Bimbingan Manasik Haji di Mihrab Qolbi Travel Tahun 2016" (Skripsi, UIN Syarif Hidayatullah Jakarta, 2017), 31.

71 "Mendengar Lebih Jelas," Instagram, dikirim oleh "daqutravel," Januari 29. https://www.instagram.com/p/B75h-t7pv1_
} 
sehingga dapat memberikan kepuasan jemaahnya.

Layanan keramahan berikutnya adalah adanya pengadaan kajian-kajian sambil menunggu waktu syuruq. Daqu Travel menginginkan agar jemaah betah berada di Masjidil Haram dan Masjid Nabawi terutama di waktu setelah Subuh. ${ }^{72}$ Sehingga dalam waktu luangpun, jemaah selalu diberikan bimbingan agar optimal menjalankan ibadah di tanah suci. Kebutuhan jemaah untuk mendapatkan ilmu agama dan pahala lainnya dapat terpenuhi ketika mengikuti kajian yang diadakan oleh Daarul Quran. Setiap Ustaz Yusuf Mansur ikut ke tanah suci bersama jemaah Daqu Travel, sekaligus memberikan tausiah kepada para jemaahnya. Salah satu materi tausiah yang diberikan seperti tema "Keseimbangan Hidup". ${ }^{73}$ Layanan ini termasuk layanan keramahan karena dapat memberikan kepuasan serta nilai tambah berupa solusi atas kebutuhan tambahan jemaahnya untuk mendapatkan pengetahuan agama tambahan sambil menunggu pelaksanaan ritual haji atau umrah selanjutnya.

Dengan adanya layanan keramahan dari pegawai Daqu Travel, pemberian fasilitas selama menginap untuk persiapan manasik, pemberian fasilitas wireless headset, dan kajian di tanah suci dapat menguatkan produk inti, sehingga makin tertarik dan puas selama menjalankan ibadah haji maupun umrah bersama Daqu Travel.

\footnotetext{
72 "Umroh Nyaman," Instagram, dikirim oleh "daqutravel," Juni 19, 2019. https://www.instagram.com/p/By4KRwspeXt/?igshi $\mathrm{d}=114$ imadub9k4p

73 "KH Yusuf Mansur - Keseimbangan Hidup," Video Youtube, 51:13, dikirim oleh "Daqu Travel Official," Maret 29, 2017. https://youtu.be/g-DsSQ8-Sj4.
}

\section{7) Layanan penyimpanan}

Produk tambahan selanjutnya yaitu Daqu Travel menyediakan asuransi perjalanan untuk para jemaahnya selama proses menjalankan ibadah ke tanah suci. Layanan penyimpanan menurut Lovelock tidak hanya untuk mengamankan barang konsumennya, melainkan juga peduli dengan keselamatan dan keamanan pasarnya. ${ }^{74}$ sehingga adanya asuransi dapat menjadi wujud kepedulian Daqu atas keselamatan dan keamanan pelanggannya, meskipun itu juga sudah menjadi hal standar bagi travel haji dan umrah lainnya. Asuransi perjalanan yang diberikan oleh Daqu Travel meliputi asuransi jiwa dan kehilangan bagasi. ${ }^{75}$ Layanan tersebut dapat membuat jemaah terjamin keselamatan dan keamanannya, selama proses menikmati produk inti. Jika terjadi kecelakaan, secara otomatis Daqu Travel akan bertanggung jawab untuk membiayai pengobatan kecelakaan serta mengganti barang milik jemaah yang hilang.

\section{8) Layanan pengecualian}

Daqu Travel juga menyediakan layanan pengecualian untuk jemaah. Salah satunya berupa pengadaan pernikahan di Masjidil Haram sekaligus menjalankan ibadah umrah, sehingga keluarga pasangan tersebut menjalankan umrah untuk menyaksikan pernikahan putra dan putrinya. Bahkan jemaah tersebut melakukan latihan ijab kabul yang diajarkan oleh pembimbing Daqu Travel. ${ }^{76}$ Pihak Daqu

\footnotetext{
${ }^{74}$ Lovelock, Manajemen Pemasaran Jasa, 202.

75 "Profil Perusahaan," DAQU TOUR AND TRAVEL: Umroh, Haji dan Wisata Muslim, diakses 08 Oktober 2019, https://daqu-travel.com/profilperusahaan.html.

76 "Pernikahan Di Masjidil Haram - Umroh Riyadhoh 11 Februari 2019," Video Youtube, 36:47, dikirim oleh
} 
Travel menerima permintaan dari jemaah, bahkan memberikan bantuan dalam proses pernikahan tersebut. Layanan ini tergolong dalam layanan pengecualian sebagaimana konsep Lovelock pada layanan permintaan khusus. ${ }^{77}$ Karena layanan yang diberikan oleh Daqu Travel tersebut merupakan pelayanan yang berkaitan dengan kebutuhan personal atau permintaan yang dilihat dari sudut pandang jemaahnya. Sehingga dapat membuat jemaah merasa puas karena Daqu Travel ternyata mampu memenuhi kebutuhan dan keinginan khusus mereka.

\section{9) Layanan tambahan lainnya}

Layanan yang diberikan untuk jemaah Daqu Travel tidak hanya sebatas persiapan maupun saat pelaksanaan ibadah haji dan umrah saja, walau pelaksanaan ibadah umrah maupun haji sudah berakhir, bukan berarti tali komunikasi dan silaturahmi antara Daqu Travel dengan para jemaahnya terputus. PPPA Daarul Quran memiliki komunitas alumni jemaah Daqu Travel untuk bertukar informasi dan memberikan respon baik positif maupun negatif demi perbaikan dan kemajuan Daqu Travel. ${ }^{78}$ Daqu Travel mengajak para alumni jemaah haji maupun umrah untuk mengikuti kegiatan kajian Islam. Ada dua kajian yang digunakan untuk melakukan pertemuan dengan para jemaah maupun alumni jemaah baik haji maupun umrah. Di antaranya, kegiatan "Kajian Rindu Baitullah" yang dilaksanakan satu bulan

“DAQU Travel Official,” Februari 19, 2019. https://www.youtube.com/watch?v=7CaQ619lem4.. 77 Lovelock, Pemasaran Jasa, 108.

78 Natasari, "Strategi dan Pelaksanaan Komunikasi Pemasaran Terpadu DAQU Travel Tahun 2013," $92-$ 93.

79 "Yang Ngaku Rindu Baitullah," Instagram, dikim oleh "daqutravel," Maret 16, 2018. https://www.instagram.com/p/BgYp3y7BIrQ/ sekali yaitu setiap minggu ketiga mulai dari jam 09.00-12.00, di Masjid Al Latief Pasar Raya Blok M Jakarta Selatan. ${ }^{79}$ Serta kegiatan "Kajian Islam Bulanan" bersama Ustaz Yusuf Mansur, dilaksanakan selama satu bulan sekali yaitu setiap minggu keempat mulai dari jam 07.30 hingga 11.30 di Masjid Istiqlal di jalan Taman Wijaya Kusuma, DKI Jakarta. ${ }^{80}$

Selain mengadakan kajian, Daqu Travel mengadakan acara "Silaturahmi Alumni Jemaah Haji dan Umrah Daqu Travel". Tujuan adanya acara tersebut sebagai bentuk persaudaraan baik antar jemaah maupun jemaah dengan pengurus Daqu Travel. Penyelenggaraan acara silaturahmi tersebut biasanya diadakan di Pesantren Daarul Quran Ketapang yang dihadiri oleh para Pembimbing Daqu Travel maupun Ustaz Yusuf Mansur. Ustaz Yusuf Mansur dalam acara silaturahmi tersebut terus mengajarkan dan memberikan motivasi kepada para alumni jemaah. ${ }^{81}$ Tidak hanya menjalankan ibadah umrah maupun haji, melainkan mendapatkan ilmu agama dan pahala lainnya ketika mengikuti kajian yang diadakan oleh Daarul Quran. Serta dapat memanfaatkan waktu luang setelah pulang dari tanah suci untuk memperdalam ilmu pengetahuan agama dan digunakan untuk terus beribadah dan bermunajat kepada Allah, sehingga kebutuhan jemaah selain ke tanah suci yaitu untuk belajar dan mendalami Islam dapat terpenuhi dengan adanya kajian tersebut. Layanan ini belum

80 "Bismillahirrahmanirrahim." Instagram dikirim oleh "daqutarvel," Februari 21, 2018. https://www.instagram.com/p/BfdSxvYgemq/.

81 "Daqu Travel Haji dan Umroh," Facebook, dikirim oleh "Daqu Travel," Juni 13, 2016. https://m.facebook.com/DaQu.Tour.Travel/photos/a $.110036802480184 / 649260115224514 /$ ?type=3\&sou rce $=54$. 
ditemukan kategorisasinya dalam delapan layanan tambahan teori Pemasaran Jasa Christopher Lovelock (the flower service), karena layanan ini diberikan kepada jemaah setelah selesai mengonsumsi produk Daqu Travel, sedangkan dalam teori Pemasaran Jasa Christopher Lovelock layanan tambahan diberikan sebelum hingga selesai mengonsumsi produk inti. Namun layanan ini dapat menjadi produk pelengkap yang memiliki nilai tambah serta daya tarik karena mampu memberikan solusi atas kebutuhan tambahan dari para jemaahnya yaitu kebutuhan mendapatkan pengetahuan agama, pemenuhan kebutuhan sosial yaitu dengan mengikuti komunitas alumni daqu travel. Apalagi jemaah haji yang memiliki waktu menunggu cukup lama untuk menunggu antrian, di masa tunggu tersebut jemaah juga diberikan layanan kajian ini oleh Daqu Travel. Adanya kajian tersebut merupakan momen untuk menyampaikan nilai-nilai dakwah kepada jemaah maupun alumni jemaah.

\section{Kesimpulan}

Berdasarkan pembahasan pada studi ini, produk jasa yang dimiliki Daqu Travel sangat beragam, mulai dari produk inti hingga layanan tambahan yang makin menguatkan nilai produk intinya.

Produk inti Daqu Travel pada permukaannya hampir sama dengan biro perjalanan haji dan umrah lainnya. Namun terdapat keunikan yang khas yaitu adanya program Quran Call yang mendampingi produk inti tersebut sehingga Haji dan Umrah Daqu Travel adalah Haji dan Umrah yang juga bagus bacaan Qurannya. Juga diberikan produk inti adanya pembimbing yang berasal dari Pesantren Daarul Quran yang memiliki kelebihan dalam hafalan Quran dan pemahaman agama, kemudian adanya jasa bimbingan khatam Quran di tanah suci bagi jemaah Haji dan Umrah, yang makin melengkapi nilai ibadah, bukan hanya memenuhi rukun Islam kelima namun juga makin bertambah amalan dan pahalanya di tanah suci.

Produk inti tersebut ditopang oleh delapan layanan tambahan yang oleh Lovelock disebut The Flower of Service. Pertama, layanan informasi yang diberikan komplet melalui website, Instagram, YouTube, WhatsApp, dan telepon yang kesemuanya mudah diakses kapan saja dan dari mana saja. Kedua, layanan penerimaan pesanan secara langsung maupun online yang sopan, cepat, akurat, dan efisien. Ketiga, layanan penagihan dan pembayaran yang cukup terintegrasi, bisa dilakukan lewat aplikasi Daqu, dan pada pembayarannya terdapat nilai pahala karena adanya sedekah otomatis. Yaitu menyisihkan sebagian pembayaran untuk pengembangan PPPA Daarul Quran, disamping juga disediakan simproh bagi jemaah yang ingin menabung.

Keempat, layanan konsultasi menyediakan solusi dan bimbingan bagi jemaah yang kesulitan dalam mempersiapkan pemberangkatan, hingga saat pelaksanaan di tanah suci. Kelima, layanan keramahan yang diwujudkan dalam sikap pegawai yang ramah, penginapan manasik di hotel hingga sebelum keberangkatan haji/umrah, pemberian wireless headset di tanah suci, hingga tausiah keagamaan di waktu luang ritual ibadah haji/umrah. Keenam, layanan penyimpanan yaitu layanan asuransi standar. Ketujuh, layanan pengecualian seperti pemenuhan permintaan pernikahan 
di tanah suci, dan permintaan khusus lain dari jemaah.

Hal lain yang belum terdapat dalam layanan tambahan Lovelock adalah adanya layanan pasca pembelian berupa kajian lanjutan bagi alumni Daqu Travel, yang ini pelaksanaannya bekerja sama dengan PPPA Daarul Quran. Sehingga meski telah usai ibadah, mereka masih dapat bersilaturahmi dalam komunitas agama.

Produk inti dan layanan tambahan yang dimiliki menunjukkan adanya sisipan nilainilai dakwah pada travel haji dan umrah ini. Sehingga produk jasa yang ditawarkan mampu memadukan antara kepentingan profit dan misi dakwah yang cukup unik. Hal tersebut juga terbukti menarik minat para jemaah yang memilih Daqu dan menjadi nilai keunggulan travel ini.

Dari studi produk jasa Daqu Travel dari perspektif pemasaran jasa, diharapkan mampu melengkapi khazanah keilmuan manajemen dakwah khususnya pada perumusan produk jasa pada lembagalembaga bermuatan dakwah. Bagi para dai, juga dapat menjadi referensi untuk menyisipkan nilai-nilai agama pada produk institusi jasa selainnya.

\section{Bibliografi}

Arsyad, Abdul Rahman. "Pelayanan Masjid Kota (Masjid Sigi Lamo Kesultanan Ternate)." EC: Journal Educandum vol.4, no. 1 (2018): 84-94. https://blamakassar.e-journal.id/educandum/article/download/69/50/.

Azmy, Mohammad Savier dan Asnan Furinto. "Analisa Faktor-Faktor Yang Mempengaruhi Persepsi Konsumen Dalam Pemilihan Biro Perjalanan Umroh dan Haji Khusus." Journal of Business Strategy and Executio vol. 1, no. 1 (2008): 171-193. https://journal.binus.ac.id/index.php/JBSE/article/view/179.

Dewi, Subkhani Kusuma. "Trend Wisata Umrah: Antara Meneladani Sunnah dan Turisme Spiritual." Empirisma vol. 26, no. 2 (2017): 191-205. DOI: 10.30762/empirisma.v26i2.691.

Fatona, Siti. "Kualitas Jasa Yang Mempengaruhi Loyalitas dan Relevansinya Terhadap Kepuasan." Jurnal Dinamika Manajemen vol. 1, no. 1 (2010): 41-46. https://journal.unnes.ac.id/nju/index.php/jdm/article/view/2448.

Hartinah, Siti. "Deskripsi Produk Dakwah Masjid Jogokariyan Yogyakarta Periode tahun 2000-2018." Skripsi, STID Al Hadid Surabaya, 2018.

Kifli, Dzul. "Manajemen Pelayanan Jamaah Haji dan Umrah PT. Patuna Tour dan Travel." Skripsi, UIN Syarif Hidayatullah Jakarta, 2010. http://repository.uinjkt.ac.id/dspace/handle/123456789/2011.

Kotler, Philip and Gary Armstrong. Prinsip-prinsip Pemasaran. Edisi 12. Jakarta: Erlangga, 2008.

Kotler, Philip and Kevin Lane Keller. Manajemen Pemasaran Edisi 12. Jakarta: PT Indeks, 2007. 
Kotler, Philip andKevin Lane Keller. Manajemen Pemasaran Edisi 13 Jilid 2. Jakarta: Erlangga, 2009.

Lovelock, Christopher, Jochen Wirzt, and Jacky Mussry. Pemasaran Jasa Manusia, Teknologi, Strategi perspektif Indonesia jilid 1. Jakarta: PT Erlangga, 2010.

Lovelock, Christopher H. and Lauren K. Wright. Manajemen Pemasaran Jasa. Jakarta: Indeks, 2005.

Miles, Matthew B. and A. Michel Huberman. Analisis Data Kualitatif. Translated by Tjetjep Rohendi Rohidi. Jakarta: UI Press, 1992.

Natasari, Pueri Sa'ada. "Strategi dan Pelaksanaan Komunikasi Pemasaran Terpadu DAQU Travel Tahun 2013." Skripsi, Universitas Muhammadiyah Jakarta. 2015. http://repository.umi.ac.id/handle/123456789/770.

Padillah, Ridwan Nur dan Hestya Patrie. "Upaya Peningkatan Pelayanan dan Loyalitas Customer di PT. Al Amin Mulia Lestari." Jurnal Idealis vol. 1, no. 5 (2018): 226232. http://jom.fti.budiluhur.ac.id/index.php/IDEALIS/article/view/1009.

Reza, Muhammad. "Evaluasi Pelayanan Bimbingan Manasik Haji di Mihrab Qolbi Travel Tahun 2016." Skripsi, UIN Syarif Hidayatullah Jakarta, 2017.

http://repository.uinjkt.ac.id/dspace/handle/123456789/49059

Rostanti, Qommaria. "Daqu Travel Ajak Jamaah Umrah Khataman Alquran." Republika.co.id. Juli 23, 2019. https://www.republika.co.id/berita/jurnal-haji/berita-jurnalhaji/17/04/05/onxmbi313-daqu-travel-ajak-jamaah-umrah-khataman-alquran.

Sugiyono. Memahami Penelitian Kualitatif. Bandung: Alfabeta CV, 2010.

Sutio, Muhammad. "Pengaruh Tingkatan Produk Terhadap Loyalitas Pelanggan (The Effect of Product Level On Customer Lotalty)." Jurnal Digest Marketing vol. 3, no. 1 (2018): 53-58. https://online-journal.unja.ac.id/digest/article/view/4403

Tania, Ajeng. "Analisis Program Pelayanan Jama'ah Haji dan Umroh PT. Arminareka Perdana." Skripsi, UIN Syarif Hidayatullah Jakarta, 2014. http://repository.uinjkt.ac.id/dspace/handle/123456789/26416

Tjiptono, Fandy. Strategi Pemasaran Edisi 4. Yogyakarta: CV. Andi, 2014.

Ulum, Miftahul. "Pembinaan Kompetensi Ustadz Madrasah Diniyah Melalui Program Tarbiyatul Mu'allimin di Madrasah Diniyah Takmiliyah Awwaliyah Ar-Rosyidiyah Mambaul Ulum Pangarengan Sampang." Modeling: Jurnal Program Studi PGMI vol. 6, no. 2 (2019): 137161. DOI: $10.36835 /$ modeling.v6i2.448.

"7 Alasan Kenapa Umroh Dengan Daqu Travel?." DAQU TOUR AND TRAVEL. April 01, 2020. https://daqu-travel.com/7-alasan-kenapa-umroh-dengan-daqutravel.html.

"Beginilah Kami Melayani Tamu Allah - Manasik Umrah Daqu Travel." Video Youtube. 4:54. Dikirim oleh "Daqu Travel Banten," Maret 20, 2019. https://youtu.be/a9wPaqpC6ME.

"Berencana Umroh Dalam Waktu Dekat?." DAQU TRAVEL. September 19, 2019. https://www.daqutravelbanten.com/umroh-2019/.

"Bismillahirrahmanirrahim." Instagram. Dikirim oleh "daqutarvel," Februari 21, 2018. https://www.instagram.com/p/BfdSxvYgemq/. 
"Brosur Haji Terbaru." DAQU TRAVEL. September 17, 2019. https://daqutravel.com/haji.

"Daqu Travel Haji dan Umroh." Facebook. Dikirim oleh "Daqu Travel," Juni 13, 2016. https://m.facebook.com/DaQu.Tour.Travel/photos/a.110036802480184/649260115224 514/?type=3\&source=54.

"Ibadah Dapat Sedekah Pun Dapat." Instagram. Dikirim oleh "daqutravel," Maret 19, 2019. https://www.instagram.com/p/BvLMYqTAZ27/?igshid=1s5mtt7f413ax.

"KH Yusuf Mansur - Keseimbangan Hidup." Video Youtube. 51:13. Dikirim oleh "Daqu Travel Official," Maret 29, 2017. https://youtu.be/g-DsSQ8-Sj4.

"Launching Program Umroh 1441 H." Video Youtube. 1:14:55. Dikirim oleh "Daqu Channel," Mei 3, 2019. https://youtu.be/vzZHBTK3xZk.

"Melebihi Ekspektasi." Instagram. Dikirim oleh "daqutravel," Februari 20, 2019. https://www.instagram.com/p/BuGY6AHAJjz/?igshid=4pohvw2nbl46.

"Mendengar Lebih Jelas." Instagram. Dikirim oleh "daqutravel," Januari 29. https://www.instagram.com/p/B75h-t7pv1_/.

"Mengapa Memilih Daqu Travel?." DAQU TRAVEL. Juli 23, 2019. https://daqutravel.com/home.

"Pernikahan Di Masjidil Haram - Umroh Riyadhoh 11 Februari 2019." Video Youtube. 36:47. Dikirim oleh "DAQU Travel Official," Februari 19, 2019. https://www.youtube.com/watch?v=7CaQ619lem4.

"Profil Perusahaan." DAQU TOUR AND TRAVEL: Umroh, Haji dan Wisata Muslim. September 2, 2019. https://daqu-travel.com/tentang-kami.

"Profile Daqu Travel," video Youtube, 7:57, dikirim oleh "Nano Rangga MC," diakses 02 November 2019. https://youtu.be/7Da81virNSM.

"Qur'an Call." PPPA Daarul Qur'an. Oktober 08, 2019. https://pppa.id/program/quran_call.

"Simpanan Umroh." Instagram. Dikirim oleh "daqutravel," Desember 29, 2016. https://www.instagram.com/p/BOmKw4Thdry/?igshid=7un1dyhuv5758.

"Umroh Nyaman." Instagram. Dikirim oleh "daqutravel," Juni 19, 2019. https://www.instagram.com/p/By4KRwspeXt/?igshid=114imadub9k4p.

"Yang Ngaku Rindu Baitullah." Instagram. Dikim oleh "daqutravel," Maret 16, 2018. https://www.instagram.com/p/BgYp3y7BIrQ/. 
Santika Pertiwi

200 | INTELEKSIA - Jurnal Pengembangan IImu Dakwah 